\title{
The Macroeconomic Determinants of Stock Market Development in Selected European Countries: Dynamic Panel Data Analysis
}

\author{
Deniz Şükrüoğlu ${ }^{1} \&$ Halime Temel Nalin ${ }^{2}$ \\ ${ }^{1}$ Department of Economics, Bulent Ecevit University, Zonguldak, Turkey \\ ${ }^{2}$ Department of Business, Bulent Ecevit University, Turkey \\ Correspondence: Deniz Şükrüoğlu, Department of Economics, Bulent Ecevit University, Zonguldak, Turkey. Tel: \\ 90-372-257-4010 ext 1653. E-mail: dsukruoglu@gmail.com
}

Received: December 14, 2013

Accepted: December 24, 2013

Online Published: February 25, 2014

doi:10.5539/ijef.v6n3p64

URL: http://dx.doi.org/10.5539/ijef.v6n3p64

\begin{abstract}
This paper is concerned with the effects of macroeconomic variables and their role in development of stock market in selected Europen countries by estimating a dynamic panel data for the period of 1995-2011. We found that income, monetazation ratio, liquidity ratio, saving rate and inflation effect on stock market development. Monetazation ratio and inflation have negative effects while income, liquidity ratio, saving rate have positive effects on stock market development. Liquidity ratio emphasizes that the stock market liquidity help to improve stock market development. Furthermore, income and saving rate are correlated with stock market growth.
\end{abstract}

Keywords: stock market development, macroeconomic determinants, dynamic panel data

\section{Introduction}

Since recently, researchers have shown an increased interest in macroeconomic variables and development of stock market for different countries. Macroeconomic factors have a significant impact on stock market performance. Many studies have been related to the economic factors and their interrelation with the stock market development. The financial system faciliate the trading, hedging, diversifying, pooling risk and mobilize saving. It can help to improve resource allocation problem (Levine, 1997). Well functioning the financial regulation and government management provide financial sector development. New European countries passed substantial alteration during the transitional period. Many countries carried out important reforms after the collapse of communism in Soviet Union, successfully adapted to European structures and after the earlier stage of transition experienced steady growth (Horvath \& Petrovski, 2013).

It is agreed that stock markets have a significant role on the economic growth, which provide the same function as financial sector development. The relationship between stock markets and economic development has been analyzed by many of empirical researcher. Such as, King and Levine (1993), Atje and Jovanovic (1993), Demirguc-Kunt and Levine (1996), Singh (1997), Levine (1997) and Levine and Zervos (1998) reviewed in their studies that stock market development is deal with economic growth. This paper provides an empirical analysis of relationship between stock market development and its determinants in selected European countries over the period 1995-2011.

This paper is organized as follows; in the second section, we present review the literature about stock market development. Section 3 discusses our empirical methodology and definition of variables. We present also our empirical results. Section 4 contains conclusions.

\section{Literature Review}

Many studies have shown the effects of macroeconomic variables on stock market development in different countries. Levine and Zervos (1998) implied that stock market development has positively impact long-run economic growth. Mohtadi and Agarwal (2004) examined that there was the relationship between stock market development and some variables (turnover ratio, economic growth, foreign direct investment, investment, secondary school registering) for 21 emerging countries over a period of twenty years (1977-1997) using a dynamic panel method. They found that economic growth, foreign direct investment, and secondary school registering and investment are important variables as determinants of stock market development. 
Furhermore, Garcia and Liu (1999) explored the macroeconomic determinants (real income, saving, financial intermediary efficiency, stock market liquidity and inflation of stock market development on fifteen industrial and developing countries (Argentina, Brazil, Chile, Colombia, Indonesia, Japan, Korea, Malaysia, Mexico, Peru, Philippines, Taiwan, Thailand, United States and Venezuela) from 1980 through 1995. They showed that real income level, saving rate, financial intermediary efficiency and stock market liquidity are effective indicators of stock market development.

In another study, Rousseau and Wachtel (2000) examined the impact of the 47 capital markets on its economic growth with panel data by using the GMM to annual data from the period of 1980-1995. They showed that liquid stock markets had a significant and subsequent impact on economic growth.

Naceur et al. (2007) found that saving, financial institutions, stock market liquidity and inflation are important determinants of stock market development. The empirical study covered the time period 1979-1999. They also used analysis of panel data in 12 MENA region countries. Naceur and Ghazouani also (2007) investigated whether there was a connection between stock markets banks and economic development. Using dynamic panel model with GMM. in 11 MENA countries covered over the period (1979-2003). They could not establish any significant link between stock market development and growth. These results are consistent with Sahu (2011) research. He investigated the causal relationship and the direction of causality between stock market development economic growth in India by for the period from1981 to 2006. He found no causal relationship between Indian stock market and economic growth.

Billmeier and Massa (2009) assessed the macroeconomic determinants (institutions, remittances, income, invesment, inflation change, domestic credit, stocks traded value, oil price index, U.S. federal funds rate) of stock market development in 17 emerging stock markets in the Middle East and Central Asia by using fixed-effect panel regression. After examining the relationship on 17 countries using annual data from 19952005, their results indicate that remittances, income, invesment, oil price, Heritage Foundation's index, stocks traded value effect on stock market development.

Results of Yartey comparative study (2010) indicated that income level, gross domestic investment, banking sector development, private capital flows and stock market liquidity are important indicators of stock market development. He used panel data of 42 emerging countries for the period 1990 to 2004.

Using panel data, Cherif and Gazdar (2010) investigated the impact of macroeconomic determinants and institutional standart on stock market development. The study covered data of 18 years of fourteen MENA countries. They found a substantial impact of income, saving, stock market liquidity and interest rate on equity market development.

Kurach (2010) performed a panel data estimation over the period 1996-2006 in thirteen CEE countries (Bulgaria, Croatia, Czech Republic, Estonia, Hungary, Latvia, Lithuania, Poland, Romania, Russian Federation, Slovak Republic, Slovenia and Ukraine). institutional and macroeconomic factors (GDP, banking sector growth, stock market liquidity, budget balance and European Union membership) have been found to be the most important factors for the development of capital markets.

One of recent studies carried out by El-Nader and Alraimony (2011) investigated the relationship between the economic growth and capital market development in Jordan, by using VECM approach between 1990 and 2011. Their findings showed that growth rate of GDP had a negative role on stock market development. On the other hand, money supply, market liquidity, gross capital formation, inflation and domestic credit to private sector have positive and significant influences on stock market development.

Abdelbaki (2013) reached that income, investment, banking sector development, private capital flows and stock market liquidity are important determinants of Bahraini stock market development by estimating the Autoregressive Distributed Lag (ADL) model.

In 2013, Pradhan et al. used panel vector autoregression (VAR) to investigate the causal relationship among stock market development, inflation and economic development in 16 Asian countries (Hong Kong, China, India, Israel, Jordan, Korea, Pakistan, Sri Lanka, Bangladesh, Indonesia, Japan, Kuwait, Malaysia, Philippines, Singapore, Thailand and Turkey) for the period 1988-2012. Their findings showed that existence of a multitude of causal relationship among stock market development, inflation and economic growth. 
Table 1. Summary of literature review

\begin{tabular}{|c|c|c|c|c|c|}
\hline $\begin{array}{c}\text { Study } \\
\text { Authors }\end{array}$ & Data-Country & $\begin{array}{c}\text { Dependent } \\
\text { variable }\end{array}$ & Independent variables & $\begin{array}{c}\text { Estimation } \\
\text { method }\end{array}$ & Results \\
\hline $\begin{array}{l}\text { Garcia and Liu } \\
\text { (1999) }\end{array}$ & $\begin{array}{c}\text { (1980-1995) } \\
\text { ASEAN and Latin } \\
\text { America } \\
\text { USA and Japan }\end{array}$ & $\begin{array}{c}\text { stock market } \\
\text { develeopment }\end{array}$ & $\begin{array}{l}\text { income, saving rate, } \\
\text { financial intermediary, } \\
\text { stock market liquidity, } \\
\text { and inflation }\end{array}$ & $\begin{array}{c}\text { panel data } \\
\text { fixed effects }\end{array}$ & $\begin{array}{c}\text { income level, saving } \\
\text { rate, financial } \\
\text { intermediary, and stock } \\
\text { market liquidity }\end{array}$ \\
\hline $\begin{array}{c}\text { Mohtadi and } \\
\text { Agarwal (2004) }\end{array}$ & $(1977-1997)$ & $\begin{array}{l}\text { stock market } \\
\text { develeopment }\end{array}$ & $\begin{array}{l}\text { turnover ratio, growth, } \\
\text { foreign direct } \\
\text { investment, investment, } \\
\text { secondary school } \\
\text { registry. }\end{array}$ & $\begin{array}{l}\text { dynamic panel } \\
\text { method }\end{array}$ & $\begin{array}{l}\text { economic growth, } \\
\text { foreign direct } \\
\text { investment, and } \\
\text { secondary school } \\
\text { registry and domestic } \\
\text { investment }\end{array}$ \\
\hline $\begin{array}{l}\text { Naceur and } \\
\text { Ghazouani } \\
\text { (2007) }\end{array}$ & $\begin{array}{l}\text { (1979-2003) } \\
11 \text { MENA Countries } \\
\text { different time }\end{array}$ & $\begin{array}{l}\text { stock market } \\
\text { develeopment }\end{array}$ & $\begin{array}{l}\text { banks and economic } \\
\text { growth. }\end{array}$ & $\begin{array}{l}\text { dynamic panel } \\
\text { model with } \\
\text { GMM }\end{array}$ & No relationship \\
\hline $\begin{array}{l}\text { Naceur et al. } \\
\quad(2007)\end{array}$ & $\begin{array}{c}(1979-1999) \\
12 \text { Middle (MENA) } \\
\text { countries. }\end{array}$ & $\begin{array}{l}\text { stock market } \\
\text { develeopment }\end{array}$ & $\begin{array}{l}\text { income, saving rate, } \\
\text { investment, credit to } \\
\text { private sector, M3, stock } \\
\text { market liquidity, } \\
\text { inflation }\end{array}$ & $\begin{array}{l}\text { unbalanced } \\
\text { panel data }\end{array}$ & $\begin{array}{l}\text { saving rate, financial } \\
\text { intermediary, stock } \\
\text { market liquidity, } \\
\text { inflation }\end{array}$ \\
\hline Duca (2007) & $\begin{array}{l}\text { (1957-2005) } \\
\text { United States, United } \\
\text { Kingdom France, } \\
\text { Germany and Japan }\end{array}$ & $\begin{array}{l}\text { stock market } \\
\text { develeopment }\end{array}$ & economic growth & $\begin{array}{l}\text { granger- } \\
\text { causality test }\end{array}$ & $\begin{array}{c}\text { stock prices } \\
\text { granger cause economic } \\
\text { growth }\end{array}$ \\
\hline $\begin{array}{l}\text { Billmeier and } \\
\text { Massa (2009) }\end{array}$ & $\begin{array}{l}\text { (1995-2005) } \\
17 \text { Middle } \\
\text { East and Central Asia } \\
\text { countries }\end{array}$ & $\begin{array}{l}\text { stock market } \\
\text { develeopment }\end{array}$ & $\begin{array}{l}\text { remittances, income, } \\
\text { invesment, Inflation } \\
\text { change, Domestic } \\
\text { credit,stocks traded } \\
\text { value, oil price index, } \\
\text { U.S. federal funds rate }\end{array}$ & $\begin{array}{c}\text { fixed-effect } \\
\text { panel regression }\end{array}$ & $\begin{array}{l}\text { remittances, income, } \\
\text { invesment, Oil price, } \\
\text { Heritage Foundation's } \\
\text { index, Stocks traded } \\
\text { value }\end{array}$ \\
\hline $\begin{array}{l}\text { Caporale et al. } \\
(2009)\end{array}$ & $\begin{array}{c}(1994-2007) \\
\text { ten new EU members }\end{array}$ & $\begin{array}{l}\text { stock market } \\
\text { develeopment }\end{array}$ & economic growth & $\begin{array}{l}\text { granger- } \\
\text { causality test }\end{array}$ & $\begin{array}{l}\text { stock prices } \\
\text { Granger cause } \\
\text { economic growth }\end{array}$ \\
\hline Kurach (2010) & $\begin{array}{l}(1996-2006) \\
\text { thirteen CEE countries }\end{array}$ & $\begin{array}{l}\text { stock market } \\
\text { develeopment }\end{array}$ & $\begin{array}{l}\text { GDP, monetization ratio, } \\
\text { liquidity ratio, turnover } \\
\text { ratio, inflation, budget } \\
\text { balance, saving rate and } \\
\text { EU accession }\end{array}$ & panel data & $\begin{array}{l}\text { GDP, turnover ratio, } \\
\text { budget balance, and EU } \\
\text { accession }\end{array}$ \\
\hline $\begin{array}{c}\text { Cherif and } \\
\text { Gazdar (2010) }\end{array}$ & $\begin{array}{c}(1990-2007) \\
14 \text { MENA countries }\end{array}$ & $\begin{array}{l}\text { stock market } \\
\text { develeopment }\end{array}$ & $\begin{array}{l}\text { income, saving, } \\
\text { investment, financial } \\
\text { intermediary efficiency, } \\
\text { stock market liquidity, } \\
\text { interest rate and inflation }\end{array}$ & panel data & $\begin{array}{l}\text { İncome, saving, stock } \\
\text { market liquidity, and } \\
\text { interest rate }\end{array}$ \\
\hline Yartey (2010) & $\begin{array}{c}(1990-2004) \\
42 \text { emerging countries }\end{array}$ & $\begin{array}{c}\text { stock market } \\
\text { develeopment }\end{array}$ & $\begin{array}{l}\text { GDP, income level, } \\
\text { banking sector growth, } \\
\text { saving and investment. } \\
\text { stock market liquidity, } \\
\text { inflation, private capital } \\
\text { flows. institutional } \\
\text { quality }\end{array}$ & $\begin{array}{l}\text { Generalized } \\
\text { Method of } \\
\text { Moments } \\
\text { (GMM) panel } \\
\text { data }\end{array}$ & $\begin{array}{l}\text { income level, gross } \\
\text { domestic investment, } \\
\text { banking sector } \\
\text { development, private } \\
\text { capital flows and stock } \\
\text { market liquidity }\end{array}$ \\
\hline $\begin{array}{l}\text { El-Nader and } \\
\text { Alraimony } \\
\quad(2011)\end{array}$ & $\begin{array}{c}(1990-2011) \\
\text { Jordan }\end{array}$ & $\begin{array}{l}\text { stock market } \\
\text { develeopment }\end{array}$ & $\begin{array}{l}\text { money supply, GDP, } \\
\text { inflation, real exchange } \\
\text { rate, interest rate }\end{array}$ & VECM model & $\begin{array}{c}\text { money supply, inflation, } \\
\text { real exchange rate, } \\
\text { interest rate }\end{array}$ \\
\hline $\begin{array}{l}\text { Abdelbaki } \\
(2013)\end{array}$ & (1990-2007) Bahrain & $\begin{array}{l}\text { stock market } \\
\text { development }\end{array}$ & $\begin{array}{c}\text { inflation, income, } \\
\text { banking system } \\
\text { development, stock } \\
\text { market liquidity, private } \\
\text { capital flow investment } \\
\text { and saving }\end{array}$ & $\begin{array}{l}\text { autoregressive } \\
\text { distributed lag } \\
\text { model (ARDL) }\end{array}$ & $\begin{array}{c}\text { income, domestic } \\
\text { investment, } \\
\text { banking system } \\
\text { development; private } \\
\text { capital flows and stock } \\
\text { market liquidity }\end{array}$ \\
\hline $\begin{array}{l}\text { Pradhan et al } \\
\text { (2013) }\end{array}$ & $\begin{array}{c}(1988-2012) \\
16 \text { Asian countries }\end{array}$ & $\begin{array}{l}\text { stock market } \\
\text { development }\end{array}$ & $\begin{array}{l}\text { inflation and economic } \\
\text { growth }\end{array}$ & $\begin{array}{l}\text { panel VAR } \\
\text { model }\end{array}$ & $\begin{array}{l}\text { inflation and economic } \\
\text { growth }\end{array}$ \\
\hline
\end{tabular}

Caporale et al (2009) examined the causal relationship between stock market development and economic growth in 10 European Union members (Bulgaria, Czech Rep, Estonia, Hungary, Latvia, Lithuania, Poland, Romania, 
Slovakia, Slovenia) using Granger-type causality tests over the period 1994-2007. They emphasized that Granger causality runs from stock market to economic growth but not in the opposite direction. In another causality research; Duca (2007) analyzed the causality between stock market capitalization and economic growth in United States, United Kingdom France, Germany and Japan for different time periods. He found that the undirectional causality between stock market capitalization and economic growth for all countries except Germany. It has been determined that stock prices Granger cause GDP.

Table 1 presents that summary of literature review in depth. This table shows many studies about independent variables of stock market developments and their findings. According to this literature, we determined independent variables.

\section{Data and Metodology}

\subsection{Data}

We aimed that dynamic panel data analysis using annual data over the 1995-2011 period, data permitting. The data analyzed in this paper consists of economic and financial time series of 19 European countries (Austria, Belgium, Bulgaria, Croatia, Czech Republic, Denmark, Finland, France, Germany, Greece, Hungary, Italy, Latvia, Netherlands, Portugal, Slovenia, Spain, Sweden and United Kingdom). Because other 11 European countries data are missed, we selected 19 European countries. All data were obtained from the World Development Indicators (2008) database website.

Stock Market Development( SMDE): (Market Capitalization Ratio) This ratio equals the value of domestic shares divided by GDP. Market capitalization ratio is used as equity market development. We used stock market capitilazation ratio as dependent variable in our model.

We used the following indicators as explanatory variables: (Levine \& Zervos, 1998; Garcia \& Liu, 1999; Mohtadi \& Agarwal, 2004);

GDP: Log of GDP per capita is described as income level. The main driving force for development of stock market is high income. It is also important that the level of income correlates with the level of education. In addition, more educated people have known about stock market.

Turnover ratio (SMT) or Liquidity ratio (ST): We can use two measures of stock market liquidity. First of all, turnover ratio equals the total value of shares traded to market capitilization. It is a measure of the value of securities transactions relative to the size of the securities market. The second measure of market liquidity is liquidity ratio which equals total value of shares traded on the stock market exchange divided by GDP. The liquidity ratio measures the organized trading of company equity as a share of national output. The turnover and liquidity ratios complement the market capitalization ratio.

Monetization ratio (LL): Monetization ratio is a measure financial system development. The M3 (liquid liabilities) to GDP ratio is an determinant of the size of the financial system in relation to the economy as a whole.

Savings rate (GDS): Saving rate is higly related to market capitalization. Liquid equity markets provide profitability and lead to assets invesment. Consequenly, it provide resource allocation efficiency.

Inflation rate (CPI) or Budget balance (CS): These variables are used as measures of macroeconomic stability. The impact of high inflation makes stocks less attractive than low inflation.

\subsection{Methodology}

We consider following dynamic panel data model;

$$
S M D E_{i t}=\alpha+\delta S M D E_{i t-1}+\beta X_{i t}+u_{i t}
$$

Where $X_{i t}$ includes control variables. Control variables are logartihm of Gross Domestic product (L_GDP), Liquid liabilities (LL), Stocks traded \% of GDP (ST) as liquidity ratio, Stocks traded \% of market capitalization (SMT) as turnover ratio, Infliation consumer prices (CPI), Cash surplus (CS) as budget balance and finaly Gross domestic saving (GDS) as savings rate.

According to the literature the expected signs of the variables are as follows; 
Table 2. The expected coefficient signs of the variables

\begin{tabular}{cccccccc}
\hline SMDE & L_GDP & LL & ST & SMT & CPI & CS & GDS \\
\hline+ & + & + & + & + & - & + & + \\
\hline
\end{tabular}

We first check the stationarity level of the variables. For this purpose 5 panel unit root tests are used. The test results are given in Table 3 .

Table 3. Panel unit root test results

\begin{tabular}{lcccccccc}
\hline & SMDE $^{2}$ & L_GDP $^{2}$ & LL $^{3}$ & ST $^{2}$ & SMT $^{2}$ & CPI $^{2}$ & CS $^{1}$ & GDS $^{\mathbf{1}}$ \\
\hline Levin, Lin \& Chu & $-4,49^{*}$ & $-7,21^{*}$ & $-6,77^{*}$ & $-4,46^{*}$ & $-3,55^{*}$ & $-8,69^{*}$ & $-16,22^{*}$ & $-13,88^{*}$ \\
Breitung & & & 4,40 & & & & & \\
Im, Pesaran, Shin & $-6,32^{*}$ & $-2,36^{*}$ & $-3,45^{*}$ & $-4,08^{*}$ & $-2,71^{*}$ & $-6,19^{*}$ & & \\
ADF - Fisher & $107,90^{*}$ & $61,36^{*}$ & $87,11^{*}$ & $72,96^{*}$ & $57,52^{* *}$ & $113,08^{*}$ & $267,00^{*}$ & $232,07^{*}$ \\
PP - Fisher & $74,71^{*}$ & $72,08^{*}$ & $61,39^{*}$ & $58,20^{* *}$ & $59,59^{* *}$ & $127,73^{*}$ & $272,81^{*}$ & $271,02^{*}$
\end{tabular}

Note: ***,** and $*$ indicates the $0,10,05$ and 0,01 significance levels respectively;

1 There is no intercept nor trend in the test equation;

2 Only individual intercept in the test equation;

3 Individual intercept and trend in the test equation.

Table 3 shows the panel unit root test results. All the variables except CPI and GDS are found stationary in level at 5 percent significance level. CPI and GDS variables are stationary in first differences. We use first differences of GDS and CPI in the estimation procedure.

Our model has lagged dependent variables as a regressor. Then it becomes a dynamic panel data model. In this situation the estimation procedure differs. Suppose we have a simple autoregressive panel data model with no additional regressors.

$$
y_{i t}=\delta y_{i t-1}+u_{i t}
$$

Where $u_{i t}=\mu_{i}+v_{i t}$ with $\mu_{i} \square I I D\left(0, \sigma_{\mu}^{2}\right)$ and $v_{i t} \square I I D\left(0, \sigma_{v}^{2}\right)$.

In a dynamic panel data model;

- Since $y_{i t}$ is a function of $\mu_{i}$ the OLS estimator biased and inconsistent (Sevestre \& Trognon, 1985).

- The Within transformatin wipes out $\mu_{i}$ but $y_{i t-1}$ is still correlated with the $\bar{v}_{i}$ which contains $v_{i t-1}$ so the Fixed Effect estimator is biased (Nickell, 1981).

- $\quad$ The random effects GLS estimator is also biased (Anderson \& Hsiao, 1981).

First, we difference to eliminate the individual effects.

$$
y_{i t}-y_{i t-1}=\delta\left(y_{i t-1}-y_{i t-2}\right)+\left(v_{i t}-v_{i t-1}\right)
$$

$y_{i 1}$ becomes a valid instrumental variable when $t=3$. In the third period we have

$$
y_{i 3}-y_{i 2}=\delta\left(y_{i 2}-y_{i 1}\right)+\left(v_{i 3}-v_{i 2}\right)
$$

For the next period $y_{i 1}$ and $y_{i 2}$ become a valid instrumentals and so on until $\mathrm{t}=\mathrm{T}-2$. The matrix $Z_{i}$ contains all instruments for individual $\mathrm{i}$.

$$
Z_{i}=\left[\begin{array}{ccccccccccc}
y_{i 1} & 0 & 0 & 0 & 0 & 0 & \cdots & 0 & 0 & \cdots & 0 \\
0 & y_{i 1} & y_{i 2} & 0 & 0 & 0 & \cdots & 0 & 0 & \cdots & 0 \\
0 & 0 & 0 & y_{i 1} & y_{i 2} & y_{i 3} & \cdots & 0 & 0 & \cdots & 0 \\
\vdots & \vdots & \vdots & \vdots & \vdots & \vdots & \ddots & \vdots & \vdots & \ddots & \vdots \\
0 & 0 & 0 & 0 & 0 & 0 & \cdots & y_{i 1} & y_{i 2} & \cdots & y_{i T-2}
\end{array}\right]
$$


The variance covariance matrix for the differenced error terms in eq (2)

$$
E\left[\left(v_{i t}-v_{i t-1}\right)\left(v_{i t}-v_{i t-1}\right)^{\prime}\right]=\left(\frac{1}{N} \sum_{i=1}^{N} Z_{i}^{\prime} H Z_{i}\right)^{-1}=A_{N}
$$

Where $H$ is a (T-2) square matrix which has twos in the main diagonal, minus ones in the sub diagonal and the super diagonal and zeros otherwise. Pre-multiplying the eq (3) in vector form with the matrix of all instruments $\left(Z=\left(Z_{1}^{\prime}, Z_{2}^{\prime}, \ldots, Z_{N}^{\prime}\right)^{\prime}\right)$ gives

$$
Z^{\prime} \bar{y}_{i t}=\delta Z^{\prime}\left(\bar{y}_{i t-1}\right)+Z^{\prime}\left(\bar{v}_{i t}\right)
$$

GLS estimator for this model güves us the below Arellano Bond (1991) type one-step estimator.

$$
\hat{\delta_{1}}=\frac{\bar{y}_{-1}^{\prime} Z A_{N} Z^{\prime} \bar{y}}{\bar{y}_{-1}^{\prime} Z A_{N} Z^{\prime} \bar{y}_{-1}}
$$

Where $\bar{y}=\left(\bar{y}_{1}^{\prime}, \bar{y}_{2}^{\prime}, \ldots, \bar{y}_{N}^{\prime}\right)^{\prime}, \bar{y}_{i}=\left(\bar{y}_{i 3}, \bar{y}_{i 4}, \ldots, \bar{y}_{i T}\right)^{\prime}$ and $\bar{y}_{i t}=\left(y_{i t}-y_{i t-1}\right)$ A consistent estimate of avâr $(\hat{\delta})$ for arbitrary $A_{N}$ is given by

$$
\operatorname{avâr}(\hat{\delta})=N \frac{\bar{y}_{-1}^{\prime} Z A_{N} \hat{V}_{N} A_{N} Z^{\prime} \bar{y}_{-1}}{\left(\bar{y}_{-1}^{\prime} Z A_{N} Z^{\prime} \bar{y}_{-1}\right)^{2}}
$$

The optimal choice for $A_{N}$ is $\hat{V}_{N}^{-1}$ which produces two- step estimator $\hat{\delta}_{2}$

$$
\hat{V}_{N}=\frac{1}{N} \sum_{i=1}^{N} Z_{i}^{\prime} \hat{\bar{v}}_{i} \hat{\bar{v}}_{i}^{\prime} Z_{i}
$$

Where the $\hat{\bar{v}}_{i}$ are obtained from the residuals from the one-step estimaton. $\hat{\delta}_{1}$ and $\hat{\delta}_{2}$ will be asymptotically equivalent if the $v_{i t}$, are independent and homoskedastic both across units and over time. The two-step estimator is then

$$
\hat{\delta}_{2}=\frac{\bar{y}_{-1}^{\prime} Z V_{N}^{-1} Z^{\prime} \bar{y}}{\bar{y}_{-1}^{\prime} Z V_{N}^{-1} Z^{\prime} \bar{y}_{-1}}
$$

The additional regressors $x_{i t}$ could be predetermined or strictly exogenous. if $x_{i t}$ are predetermined then for the period $s\left[x_{i 1}^{\prime}, x_{i 2}^{\prime}, \ldots, x_{i s-1}^{\prime}\right]$ becomes a valid instrument. İt should be added each diagonal element of the matrix $Z_{i}$ according to $s$. When $x_{i t}$ are strictly exogenous then $\left[x_{i 1}^{\prime}, x_{i 2}^{\prime}, \ldots, x_{i T}^{\prime}\right]$ becomes valid instruments. It should be added each diagonal element of the matrix $Z_{i}$. (Bencivenga \& Smith, 1991).

Table 4 shows the Arellano-Bond type dynamic panel data parameter estimates. The instrument rank is 19 for all the equations. It is greater than the number of estimated coefficients. J-statistics can be used to test of over-identifying restrictions. Under the null hypothesis $\mathrm{j}$ statistics has chi-squared distribution with $p$ - $k$ degrees of freedoom. Where $p$ is the instrument rank and $k$ is the number of estimated parameters. Test results indicate that the null is not rejected so the models are valid.

The lag of SMDE (stock market development), LL (Monetization ratio), ST (Liquidity ratio) CPI (inflation) and GDS (saving rate) are all significant variables for all the equations. CS (budget balance) is not significant only in the EQ4 whereas SMT is significant only in the EQ7. Interestingly logartihm of GDP is not significant equation 2 through 7 . The only equation that all the variables are significant is the equation 1 . In the EQ1, not only the variables are statistically significant but also the expected signs of the coefficients are appropriate except LL. All the equations also present that LL is negative and significant. If we use CPI and ST instead of CS and SMT in the some equation then, the models have become insignificant. Hence, it may be used CPI and ST instead of CS and SMT in the model. 
Table 4. Parameter estimates

\begin{tabular}{|c|c|c|c|c|c|c|c|c|}
\hline & EQ1 & EQ2 & EQ3 & EQ4 & EQ5 & EQ6 & EQ7 & EQ8 \\
\hline \multirow{2}{*}{ SMDE (-1) } & $0,3907^{*}$ & $0,2450^{*}$ & $0,5323^{*}$ & $0,4284^{*}$ & $0,4167^{*}$ & $0,2309^{*}$ & $0,5645^{*}$ & $0,3943^{*}$ \\
\hline & $(0,0000)$ & $(0,0000)$ & $(0.0000)$ & $(0,0000)$ & $(0,0000)$ & $(0,0000)$ & $(0,0000)$ & $(0,0000)$ \\
\hline \multirow{2}{*}{$\underline{L}$ gdp } & $33,5806^{*}$ & $-0,2660$ & 33,7455 & 11,9145 & $-10,1162$ & $-5,9418$ & 27,9636 & $16,4193^{* *}$ \\
\hline & $(0,0004)$ & $(0,9776)$ & $(0.2186)$ & $(0,2656)$ & $(0,7738)$ & $(0,4176)$ & $(0,1145)$ & $(0,0119)$ \\
\hline \multirow{2}{*}{$\mathbf{L L}$} & $-0,4418^{*}$ & $-0,4413^{*}$ & $-0,4009^{*}$ & $-0,3186^{*}$ & $-0,4235^{*}$ & $-0,4302^{*}$ & $-0,4703^{*}$ & $-0,3604^{*}$ \\
\hline & $(0,0000)$ & $(0,0000)$ & $(0.0001)$ & $(0,0000)$ & $(0,0001)$ & $(0,0000)$ & $(0,0000)$ & $(0,0000)$ \\
\hline \multirow{2}{*}{ ST } & $0,1988^{*}$ & $0,2399^{*}$ & & & $0,2771^{*}$ & $0,2745^{*}$ & & \\
\hline & $(0,0000)$ & $(0,0000)$ & & & $(0,0000)$ & $(0,0000)$ & & \\
\hline \multirow{2}{*}{$\underline{\text { SMT }}$} & & & 0,0388 & $-0,0235$ & & & $0,0512^{* * *}$ & $-0,0135$ \\
\hline & & & 0,4317 & 0,5573 & & & 0,0711 & 0,5465 \\
\hline \multirow{2}{*}{ CPI } & $-9,1091^{*}$ & & $-7,8762^{*}$ & & $-6,9000^{*}$ & & $-7,5655^{*}$ & \\
\hline & $(0,0000)$ & & $(0.0000)$ & & $(0,0029)$ & & $(0,0000)$ & \\
\hline \multirow{2}{*}{ CS } & & $1,1770^{*}$ & & 0,9221 & & $1,3867^{*}$ & & $1,9458^{*}$ \\
\hline & & $(0,0087)$ & & $(0,4677)$ & & $(0,0006)$ & & $(0,0002)$ \\
\hline \multirow{2}{*}{ GDS } & $3,5730^{*}$ & $2,4754^{*}$ & $4,5292^{*}$ & $3,3241^{*}$ & & & & \\
\hline & $(0,0000)$ & $(0,0000)$ & $(0.0012)$ & $(0,0000)$ & & & & \\
\hline J stats & 13,9149 & 14,8840 & 16,3044 & 13,0695 & 11,7189 & 16,6378 & 13,1208 & 14,1019 \\
\hline Prob & 0,3798 & 0,3146 & 0,2330 & 0,4424 & 0,6288 & 0,2759 & 0,5170 & 0,4421 \\
\hline
\end{tabular}

Note: $* * 0,1 * * 0,05$ and $* 0,01$. Probabilities are in parenthesis.

\section{Conclusion}

In this paper, we have emphasized the effect of selected macroeconomic variables on stock market development for the period 1995-2011. A dynamic panel data estimation is used that covers 19 European countries. We found that income, monetazation ratio, liquidity ratio, saving rate and inflation effect on stock market development. Monetazation ratio and inflation have negative impact while income, liquidity ratio, saving rate have positive impact on stock market development. Surprisingly, monetazation ratio is measured banking sector development negatively effects on stock market development. Furthermore, stock market liquidity are important determinants of market capitalization. We found that stock market liquidity is significantly positive in our model. Income and saving rate results are consistent with literature.

\section{References}

Abdelbaki, H. H. (2013). Causality relationship between macroeconomic variables and stock market development: Evidence from Bahrain. The International Journal of Business and Finance Research, 7(1), 69-84. http://dx.doi.org/10.5539/ijef.v5n6p91

Anderson, T. W., \& Hsiao, C. (1981). Estimation of dynamic models with error components. Journal of the American Statistical Association, 76, 598-606. http://dx.doi.org/10.1016/0304-4076(82)90095-1

Arellano, M., \& Bond, S. (1991). Some tests of specification for panel data: Monte Carlo evidence and an application to employment equations. Review of Economic Studies, 58, 277-297. http://dx.doi.org/10.2307/2297968

Atje, R., \& Jovanovic, B. (1993). Stock markets and development. European Economic Review, 37, 630-640. http://dx.doi.org/10.1016/0014-2921(93)90053-D

Bencivenga, V. R., \& Smith, B. D. (1991). Financial intermediation and endogenous growth. Review of Economic Studies, 58(2), 195-209. http://dx.doi.org/10.2307/2297964

Billmeier, A., \& Massa, I. (2009). What drives stock market development in emerging markets, institutions, remittances, or natural resources. Emerging Markets Review, 10, 23-35. http://dx.doi.org/10.1016/j.ememar.2008.10.005

Caporale, G. M., Rault, C., Sova, R., \& Sova, A. (2009). Financial development and economic growth: Evidence from ten new EU members. DIW Berlin Discussion Paper 940.

Cherif, M., \& Gazdar, K. (2010). Macroeconomic and institutional determinants of stock market development in MENA region: New results from a panel data analysis. International Journal of Banking and Finance, 7(1), 139-159. 
Demirguc-Kunt, A., \& Levine, R. (1996). Stock market development and financial intermediaries. stylized facts. The World Bank Economic Review, 10(2), 291-321. http://dx.doi.org/10.1093/wber/10.2.291

Duca, G. (2007). The relationship between The stock market and the economy: Experience from international financial markets. Bank of Valletta Review, 36, 1-12.

El-Nader, H. M., \& Alraimony, A. D. (2013). The Macroeconomic determinants of stock market development in Jordan international. Journal of Economics and Finance, 5(6), 91-103. http://dx.doi.org/10.5539/ijef.v5n6p91

Garcia, F. V., \& Lin, L. (1999). Macroeconomic determinants of stock market development. Journal of Applied Economics, 2(1), 29-59.

Horvath, R., \& Petrovski, D. (2013). International stock market integration: Central and South Eastern Europe compared. Economic Systems, 37(1), 81-91. http://dx.doi.org/10.1016/j.ecosys.2012.07.004

King, R. G., \& Levine, R. (1993). Finance and growth: Schumpeter might be right. Quarterly Journal of Economics, 108, 717-738. http://dx.doi.org/10.2307/2118406

Kurach, R. (2010). Stock market development in CEE countries-The panel dataanalysis. Ekonomika, 89(3), 20 29.

Levine, R. (1997). Financial development and economic growth: Views and agenda. Journal of Economic Literature, 35(2), 688-726. http://dx.doi.org/10.1596/1813-9450-1678

Levine, R., \& Zervos, S. (1998). Stock markets, banks, and economic growth. American Economic Review, 88, 537-558. http://dx.doi.org/10.1596/1813-9450-1690

Mohtadi, H., \& Agarwal, S. (2004). Stock market development and economic growth: Evidence from developing countries. New York: Oxford University Press.

Naceur, S. B., Ghazouani, S., \& Omran, M. (2007). The determinants of stock ma rket development in the Middle-Eastern and North African Region. Managerial Finance, 33(7), 477-489. http://dx.doi.org/10.1108/03074350710753753

Nickell, S. (1981). Biases in dynamic models with fixed effects. Econometrica, 49, 1417-1426. http://dx.doi.org/10.2307/1911408

Pradhan, R. P., Arvin, M. B., Samadhan, B., \& Tanejha, S. (2013). The impact of stock market development on inflation and economic growth of 16 Asian countries: A panel var approach. Applied Econometrics and International Development, 13(1), 203-220.

Rousseau, P. L., \& Wachtel, P. (2000). Equity markets and growth: cross country evidence on timing and outcomes. Journal of Banking and Finance, 24(12), 1933-1957. http://dx.doi.org/10.1016/S0378-4266(99)00123-5

Sahu, N. C., \& Dhiman, D. H. (2011). Correlation and causality between stock market and macro economic variables in India: An empirical study. International Proceedings of Economics Development and Research, 3, 281-284.

Sevestre, P., \& Trognon, A. (1985). A note on autoregressive error component models. Journal of Econometrics, 28, 231-245. http://dx.doi.org/10.1016/0304-4076(85)90122-8

Singh, A. (1997). Financial liberalisation stock markets and economic development. The Economic Journal, 107, 771-782. http://dx.doi.org/10.1111/j.1468-0297.1997.tb00042.x

World Development Indicators Database. (2008). The World Bank. Washington.

Yartey. (2010). The institutional and macroeconomic determinants of stock market development in emerging $\begin{array}{llll}\text { economies. } & \text { Applied } & \text { Financial }\end{array}$ http://dx.doi.org/10.1080/09603107.2010.522519

\section{Copyrights}

Copyright for this article is retained by the author(s), with first publication rights granted to the journal.

This is an open-access article distributed under the terms and conditions of the Creative Commons Attribution license (http://creativecommons.org/licenses/by/3.0/). 